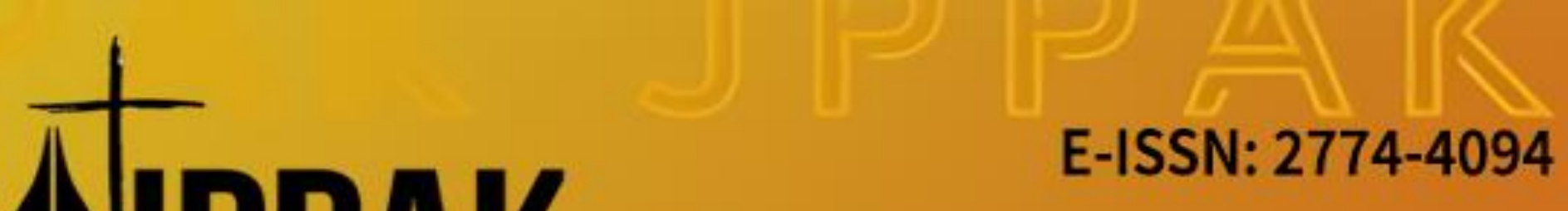




\title{
Dewan Editor
}

\author{
JPPAK (Jurnal Penelitian Pendidikan Agama Katolik) \\ E-ISSN: 2774-4094 (Online) \\ DOI Prefix: 10.52110
}

Pemimpin Redaksi dan Manajer Jurnal JPPAK:

(Pst.) Ferry Hartono, S.S., Lic. S.S. (STIKAS Santo Yohanes Salib, Kalbar)

\section{Wakil-wakil Pemimpin Redaksi:}

1. Dr. Albertus Heriyanto, M.Hum. (STFT Fajar Timur Jayapura)

2. (Pst.) Fransiskus Zaverius M. Deidhae, M.A. (STP Atma Reksa Ende)

\section{Editor-editor Pelaksana:}

1. Yosua Damas Sadewo, M.Pd.

2. Silvester, M.Pd.

3. Pebria Dheni Purnasari, M.Pd.

\section{Admin OJS:}

Azriel Christian Nurcahyo, M.Kom.

\section{Editor Desain dan Tataletak:}

Yosua Damas Sadewo, M.Pd.

\section{Mitra Bebestari:}

1. (Pst.) Prof. Dr. Armada Riyanto, STFT Widya Sasana, Malang, Jatim

2. Dr. Basilius Redan Werang, S.S., S.Sos., JCL, Universitas Musamus, Merauke

3. Dr. Paskalis Edwin I Nyoman Paska, STP-IPI, Malang, Jatim

4. (Rev.) Gilbert Duuk, STL., St. Peter's College, Kuching, Sarawak, Malaysia

5. (Pst.) Dr. Carolus Patampang, S.S., M.A., Sekolah Tinggi Kateketik dan Pastoral Rantepao, Toraja, Makassar, Sulawesi Selatan.

6. (Pst.) Ignasius Samson Sudirman Refo, STPAK St. Yohanes Penginjil, Ambon, Maluku

7. Capt. Cahya Fajar Budi Hartanto, M.Mar., M.Si., Politeknik Bumi Akpelni, Semarang, Jateng.

8. Vinsensius Crispinus Lemba, S.Fil., M.Pd., Institut Keguruan dan Teknologi, Larantuka, NTT. 


\title{
DAFTAR ISI
}

\author{
JPPAK (Jurnal Penelitian Pendidikan Agama Katolik) \\ ISSN: 2774-4094 (online) \\ DOI Prefix: 10.52110 \\ Volume 1 Nomor 1, Maret 2021
}

Analisis Karakteristik Gaya Belajar VAK (Visual, Auditorial, Kinestetik) Siswa

Kelas X SMAK St. Petrus Ende Tahun Ajaran 2019/2020

\section{Norbertus Labu}

Upaya Meningkatkan Kinerja dan Kompetensi Guru Pendidikan Agama

Katolik di Papua

Donatus Wea

Pemanfaatan Media pada Pembelajaran Pendidikan Agama Katolik Tingkat

Sekolah Dasar

Suko; Thomas Kuslin; Martinus Marthin

Analisis Hubungan antara Iman kepada Tuhan Yesus Kristus, Putera Allah

$66-89$ dan Penghayatan Hidup Doa Para Frater CSE Komunitas Studi Landak,

Kalimantan - Barat

\section{Angelo Luciani Moa Dosi Woda}

Evaluasi Pelaksanaan Katekisasi Sakramen Penguatan di Rayon I Kota

$90-109$

Semarang

Hartutik; Markus Dwi Setiawan

Pengaruh Pendidikan Karakter terhadap Kecerdasan Emosional Remaja

Kelas XI di SMA Negeri 1 Malaka Barat Besikama

Anselmus Yata Mones; Cresensius Paulus Boli Toba 


\title{
Analisis Karakteristik Gaya Belajar VAK (Visual, Auditorial, Kinestetik) Siswa Kelas X SMAK St. Petrus Ende Tahun Ajaran 2019/2020
}

\author{
Norbertus Labu ${ }^{1)}$ \\ 1) Sekolah Tinggi Pastoral Atma Reksa, Flores, Indonesia \\ Email: norlabu@yahoo.co.id
}

ARTICLE INFO

Article History

Received 21-09-2020

Revised 10-10-2020

Accepted 01-12-2020

Kata Kunci:

Gaya belajar; Visual; Auditorial; Kinestetik

\section{Keywords:}

Learning style; Visual; Auditory; Kinesthetic

\section{A B S T R A K}

Penelitian ini bertujuan untuk mendeskripsikan karekteristik gaya belajar VAK (visual, auditorial, kinestetik) siswa atau peserta didik di tingkat SMA. Gaya belajar merupakan modalitas belajar yang sangat penting. Informasi yang berhubungan dengan karakteristik gaya belajar siswa sangat penting bagi guru sehingga guru dapat memilih strategi pembelajaran yang tepat, yang dengan demikian akan meningkatkan kualitas pembelajarannya. Siswa juga akan lebih mudah memotivasi dirinya dalam mengikuti pembelajaran. Penelitian ini adalah penelitian nonekspereimen dan tergolong dalam penelitian deskriptif analitis kualitatif. Subjek penelitian ini adalah seluruh siswa kelas $X$ SMAK St. Petrus Ende tahun ajaran 2019/2020. Instrumen yang digunakan dalam penelitian ini berupa angket/kuesioner yang diisi oleh subjek penelitian. Angket gaya belajar ini diisi 189 siswa kelas X SMAK St. Petrus Ende tahun ajaran 2019/2020. Hasil analisis gaya belajar siswa kelas Xa didominasi oleh gaya belajar auditorial $(50 \%)$. Kelas $\mathrm{Xb}$ didominasi oleh gaya belajar auditorial $(60,53 \%)$. Kelas Xc didominasi oleh gaya belajar auditorial $(68,42 \%)$. Kelas Xd didominasi oleh gaya belajar gabungan visual dan auditorial $(37,84 \%)$. Kelas Xe didominasi oleh gaya belajar auditorial $(55,27 \%)$. Secara keseluruhan gaya belajar siswa kelas $X$ SMAK St. Petrus Ende angkatan 2019/2020 didominasi oleh gaya belajar auditorial, yaitu sebesar $52,91 \%$.

\section{A B STRACT}

This research aims to describe the characteristics of the VAK (visual, auditory, kinesthetic) learning styles of students or learners. Learning style is a very important learning modality. Information relating to the characteristics of student learning styles is very important for the teacher so that the teacher can choose a fixed learning strategy, which will thus improve the 
quality of learning. Students will also more easily motivate themselves in learning. This research is non-experimental and classified as a qualitative analytical descriptive study. The subjects of this research were all students of class X SMAK St. Petrus Ende 2019/2020 school year. The instrument used in this research was a questionnaire filled out by research subjects. This learning style questionnaire was filled out by 189 students of class X of SMAK St. Petrus Ende 2019/2020 school year. The results of the analysis of the learning styles of class $X a$ students are dominated by auditory learning styles (50.00\%). Class $X b$ is dominated by auditory learning styles (60.53\%). Class $X_{C}$ is dominated by auditory learning styles $(68.42 \%)$. Class $X d$ is dominated by a combined visual and auditory learning style (37.84\%). Class $X e$ is dominated by auditory learning styles (55.27\%). Overall learning styles of class X students of SMAK St. Petrus Ende class of 2019/2020 is dominated by auditory learning style that is equal to $52.91 \%$.

\section{PENDAHULUAN}

Keberhasilan proses belajar-mengajar di sekolah sangat ditentukan oleh dua subjek pembelajaran, yaitu guru dan siswa. Guru sebagai pengajar bertugas untuk menciptakan suasana belajar siswa yang kondusif, yang dirancang secara sengaja dan berkesinambungan, sedangkan siswa sebagai subjek pembelajaran adalah pihak yang menikmati suasana belajar yang diciptakan oleh guru. Interaksi antar-kedua subjek pembelajaran ini harus merupakan interaksi edukatif yang hidup, yang syarat nilai dan bertujuan untuk mengembangkan semua potensi yang ada dalam diri siswa. Dalam interaksi ini, menurut Majid (Talibo, 2013) siswa bukanlah objek pembelajaran dan guru subjek pembelajaran seperti dalam rumusan proses belajar-mengajar tradisional, tetapi siswa adalah subjek pembelajaran dan menjadi inti dari setiap kegiatan pembelajaran. Guru, sebagaimana dikemukakan oleh Gilakjani \& Ahmadi (Awla, 2014) merupakan fasilitator yang membantu siswa untuk menemukan dan mengembangkan seluruh potensi dirinya.

Salah satu faktor yang perlu diperhatikan dalam proses pembelajaran demi pengembangan potensi diri siswa adalah gaya belajar. Menurut Santrock (Papilaya \& Huliselan, 2016), "gaya belajar merupakan cara yang dipilih seseorang untuk menggunakan kemampuannya, berhubung dengan cara belajar yang disukai". Gaya belajar memainkan peran penting dalam proses pembelajaran. Gaya belajar adalah cara termudah yang digunakan seseorang untuk menerima informasi dari lingkungan, menyerap, mengatur dan mengolah informasi tersebut (Bire, Gerardus, \& Bire, 2014). Dalam hal ini, gaya belajar merupakan cara yang 
sifatnya individual untuk memperoleh dan menyerap informasi dari lingkungannya, termasuk lingkungan belajar. Joko (Wahyuni Y. , 2017) menandaskan bahwa "Gaya belajar (learning styles) merupakan suatu proses gerak laku, penghayatan, serta kecenderungan seorang pelajar mempelajari atau memperoleh suatu ilmu dengan cara yang tersendiri". Gaya belajar merupakan kombinasi antara aspek menangkap atau menyerap informasi melalui melihat, mendengar, menulis, berkata dan menyentuh dengan aspek pemrosesan informasi; mengatur dan mengolah informasi. Kolb (Ghufron \& Risnawita, 2013) mengatakan bahwa gaya belajar adalah metode yang dimiliki individu untuk memperoleh informasi, yang pada prinsipnya gaya belajar merupakan bagian integral dari siklus belajar aktif. Gaya belajar merupakan cara-cara yang lebih disukai oleh individu dalam melakukan kegiatan berpikir, memproses dan mengerti suatu informasi.

Para ahli telah melakukan beragam pendekatan untuk membuat pembagian jenis gaya belajar. Canfield mengembangkan Learning Style Inventory (Canfield LSI). Instrumen pemetaan gaya belajar ini dalam dunia pendidikan dikembangkan lebih lanjut oleh Kolb, yang dikenal dengan Learning Style Inventory (LSI) (Kurniawan, 2017). Howard Gardner (Kurniawan, 2017) mengembangkan satu gaya belajar lain yang komprehensif mewakili preferensi kecerdasan majemuk (multiple intelligence) yang dinamakan gaya belajar Memletics Styles Inventory dan sering disebut gaya belajar memletics. Dalam gaya belajar Memletics peserta didik dibagi dalam tujuh kelompok, yaitu: a) visual, b) aural, c) verbal, d) physical, e) logical, f) sosial, dan g) solitary.

Gaya belajar yang lain lagi adalah gaya belajar visual, auditorial, dan kinestetik (VAK) yang dikembangkan oleh Dunn dan Dunn, atau dikenal dengan Dunn and Dunn's VAK learning style model (Gantasala \& Gantasal, 2009). Gaya belajar ini didasarkan pada preferensi sensori atau modalitas indra (Chania, Haviz, \& Sasmita, 2016) dan sering menjadi rujukan. Dalam kenyataan tidak ada gaya belajar yang murni visual, atau murni auditorial, atau murni kinestetik. Yang ada hanyalah gaya belajar yang dominan visual, atau dominan auditorial, atau dominan kinestetik, atau gaya belajar gabungan, yaitu gabungan gaya belajar visual dan auditorial, gabungan gaya belajar visual dan kinestetik, dan gabungan gaya belajar auditorial dan kinestetik. Gaya belajar yang dominan tersebut mendefinisikan cara terbaik seseorang belajar memproses dan menafsirkan informasi (Gantasala \& Gantasal, 2009). 
Chatib (Sari, 2014) mengumpamakan gaya belajar seorang siswa sebagai pintu pembuka. Setiap informasi yang masuk melalui pintu tersebut akan memudahkan siswa untuk memahami dan mengingatnya. Karena itu, guru perlu membuat pemetaan gaya belajar siswa. "Pemetaan gaya belajar akan membuka referensi keberagaman variasi tentang indra dan gerbang sensori mana yang lebih diminati oleh peserta didik saat mereka belajar" (Kurniawan, 2017). Melalui pemetaan gaya belajar, siswa dibantu untuk lebih mudah menyerap materi pembelajaran dan guru dipermudah untuk membuat pemilihan media, sumber dan strategi pembelajaran yang sesuai dengan gaya belajar siswa. Kesesuaian antara ketiga hal ini dengan gaya belajar siswa akan membangkitkan minat, motivasi dan kemudahan siswa dalam belajar. Sebaliknya, menurut Smaldino, Lawther, \& Russel, guru yang kurang paham gaya belajar siswa akan merugikan siswa serta tidak sanggup menjalankan tugas utamanya untuk menjawab kebutuhan unik setiap siswa dalam usaha mencapai tingkat belajar yang maksimal (Kurniawan, 2017) dan proses pembelajaran tersebut menjadi tidak efektif. Menurut Sugihartono (Papilaya \& Huliselan, 2016) pembelajaran yang efektif adalah pembelajaran yang dapat merespons kebutuhan siswa, yang berkaitan dengan keunikan atau perbedaan antar siswa, di antaranya keunikan gaya belajar.

Setiap gaya belajar memiliki karakteristik tertentu. Karakteristik diartikan sebagai kualitas atau ciri-ciri khas (Reber \& Reber, 2016). Karakteristik gaya belajar berarti ciri khas dari gaya belajar tertentu. Guru yang mengetahui karakteristik gaya belajar siswanya akan sanggup memahami mereka, dan mampu menerapkan media dan strategi pembelajaran yang sesuai dengan gaya belajar siswa. Bagi siswa yang mengetahui gaya belajarnya akan segera akrab dengan gaya belajarnya sendiri, dan dapat menentukan langkah-langkah penting dalam belajar yang lebih cepat, tepat dan mudah. Dengan demikian, dapat dikatakan bahwa karakteristik gaya belajar yang dimiliki siswa adalah salah satu modalitas yang berpengaruh dalam proses pembelajaran, pemrosesan informasi, dan komunikasi.

Pemahaman akan karateristik gaya belajar tertentu sangat membantu guru untuk memilih strategi pembelajaran yang tepat. Strategi merupakan kata serapan dari bahasa Latin, yaitu kata strategia yang berarti seni penggunaan rencana dalam meraih suatu tujuan, istilah ini pada mulanya biasa digunakan dalam dunia militer (Direktorat Tenaga Kependidikan, 2008). Namun dalam perkembangan selanjutnya, istilah ini sudah biasa dipakai pada berbagai bidang, termasuk dalam 
pembelajaran. Menurut J.R. David (Direktorat Tenaga Kependidikan, 2008), strategi dalam pendidikan diartikan sebagai "a plan, method, or series of activities designed to achieves a particular educational goal". Sementara pembelajaran dimengerti sebagai sebuah proses. Proses pembelajaran merupakan suatu usaha untuk membuat siswa belajar, dan dalam peristiwa belajar (event learning) tersebut siswa mengalami terjadinya perubahan tingkah laku. Menurut Chauhan (Sunhaji, 2014), pembelajaran adalah upaya memberi rangsangan atau stimulus, bimbingan, pengarahan dan dorongan kepada siswa agar dalam proses belajar tersebut terjadi perubahan tingkah laku.

Strategi pembelajaran adalah rencana tindakan atau rangkaian kegiatan, termasuk penggunaan metode dan pemanfaatan pelbagai sumber daya atau kekuatan dalam pembelajaran yang didesain untuk mencapai tujuan pendidikan, yakni terjadinya perubahan tingkah laku dalam diri siswa. Selain itu, yang dirumuskan secara rinci dalam strategi pembelajaran adalah pendekatan, model, metode dan teknik pembelajaran secara spesifik. Hal ini akan memberikan manfaat bagi guru dan siswa. Guru mendapatkan gambaran yang tepat tentang siswa, yang selanjutnya dapat membantu siswa dalam kegiatan pembelajaran. Sedangkan siswa dapat terlibat aktif dalam pembelajaran dan terpenuhi kebutuhan akan belajar.

Hal yang perlu diperhatikan dalam strategi pembelajaran adalah metode dan teknik pembelajaran yang sesuai dengan gaya belajar siswa. Menurut Sari (Sari, 2014) penyerapan informasi dalam proses belajar-mengajar bergantung pada metode dan teknik yang sesuai dengan karakteristik gaya belajar siswa. Penyampaian informasi dengan metode dan teknik yang sesuai dengan gaya belajar siswa akan memungkinkan terjadinya perubahan tingkah laku dalam waktu yang relatif cepat dengan tingkat keberhasilan yang tinggi.

Para siswa kelas X SMAK St. Petrus Ende tahun ajaran 2019/2020 merupakan siswa-siswi yang baru masuk untuk menimba ilmu pada Sekolah Menengah Atas Katolik (SMAK) Santo Petrus Ende. Mereka berasal dari pelbagai Sekolah Menengah Pertama (SMP) dengan keanekaragaman latar belakang kepribadian yang belum dikenal oleh para guru di SMAK St. Petrus Ende. Hal ini dapat menjadi persoalan tersendiri bagi siswa dalam mengikuti proses belajarmengajar dan menyerap materi pembelajaran, serta dapat menimbulkan kesulitan bagi guru dalam memilih strategi pembelajaran. Beberapa faktor yang menyebabkan kesulitan dimaksud adalah pertama, gaya belajar siswa tidak sama 
satu dengan yang lain. Kedua, strategi pembelajaran yang dipilih guru belum tentu sesuai dengan gaya belajar yang dimiliki oleh siswa, karena para guru belum mengetahui gaya belajar yang dimiliki oleh para siswa. Penelitian Rochintaniawati, Wulan, \& Sriyati (Rochintaniawati, Wulan, \& Sriyati, 2009) menunjukkan bahwa sebagian besar guru yang tidak mengetahui gaya belajar siswa masih terus menggunakan media pembelajaran dalam satu rumpun, yakni visual dan verbal sehingga belum mampu mengakomodasi gaya belajar siswa.

Berdasarkan latar belakang di atas, peneliti memandang betapa penting dan bermanfaat untuk melakukan penelitian tentang gaya belajar siswa kelas $X$ SMAK St. Petrus Ende. Dalam penelitian ini peneliti hanya meneliti karakteristik gaya belajar VAK (visual, auditorial, kinestetik) pada siswa kelas X SMAK St. Petrus Ende. Adapun rumusan masalah yang diajukan dalam penelitian ini adalah bagaimana karakteristik gaya belajar VAK (visual, auditorial, kinestetik) yang dimiliki para siswa kelas X SMAK St. Petrus tahun ajaran 2019/2020? Adapun tujuan yang ingin dicapai dalam penelitian ini adalah pertama, untuk mendeskripsikan karakteristik gaya belajar VAK ( visual, auditorial, kinestetik) pada siswa kelas X SMAK St. Petrus Ende tahun ajaran 2019/2020. Kedua, mendeskripsikan strategi pembelajaran yang sesuai dengan masing-masing gaya belajar VAK (visual, auditorial, kinestetik). Manfaat penelitian ini bagi guru adalah guru mendapat informasi tentang karakteristik gaya belajar siswa pada awal tahun ajaran sehingga guru dapat merancang strategi pembelajaran yang sesuai dengan gaya belajar siswa. Bagi siswa, penelitian ini membantu siswa untuk mengetahui karakteristik gaya belajarnya sehingga mereka dibantu untuk lebih mudah mempelajari dan menyerap informasi yang sesuai dengan gaya belajarnya.

\section{METODE PENELITIAN}

Penelitian ini adalah penelitian non-eksperimental dan tergolong dalam penelitian deskriptif analitis kualitatif. Sugiyono (2015) menjelaskan bahwa penelitian deskriptif merupakan penelitian yang dilakukan untuk mengetahui keberadaan variabel mandiri, tanpa membuat perbandingan atau menghubungkannya dengan variabel lainnya. Variabel yang diteliti dalam penelitian ini adalah gaya belajar VAK (visual, auditorial, kinestetik) yang merupakan variabel mandiri. Dalam variabel mandiri ini dibahas tiga gaya belajar, yaitu gaya belajar visual, gaya belajar auditorial, dan gaya belajar kinestetik. 
Pertama, gaya belajar visual adalah gaya belajar dengan cara melihat, mengamati, memandang dan sejenisnya. Kekuatan gaya belajar ini terletak pada indra penglihatan. Dengan kata lain, indikator yang menentukan siswa memiliki gaya belajar visual adalah siswa memahami sesuatu dengan asosiasi visual.

Kedua gaya belajar auditorial adalah gaya belajar dengan cara mendengar. Siswa dengan gaya belajar ini lebih dominan menggunakan indra pendengar untuk melakukan aktivitas belajar. Atau lebih tegasnya, gaya belajar ini menempatkan pendengaran sebagai alat utama dalam menyerap informasi dan pengetahuan (Uno, 2016). Dalam kehidupan sehari-hari siswa yang memiliki gaya belajar ini sangat baik dalam hal aktivitas lisan. Indikator yang menentukan siswa memiliki gaya belajar auditorial adalah siswa belajar dengan cara mendengar dan baik dalam aktivitas lisan.

Ketiga, gaya belajar kinestetik adalah gaya belajar dengan cara bergerak, bekerja dan menyentuh atau mendapatkan sentuhan. Siswa yang memiliki gaya belajar ini, belajar dengan mengutamakan indra perasa dan gerakan-gerakan fisik. Individu kinestetik lebih suka belajar dengan cara terlibat langsung. Hal-hal yang sangat menonjol pada siswa yang memiliki gaya belajar kinestetik adalah gerakan, koordinasi, irama, tanggapan emosional dan kenyamanan fisik. Singkatnya, indikator siswa yang memiliki gaya belajar kinestetik adalah siswa belajar melalui aktivitas fisik, selalu berorientasi pada fisik dan banyak bergerak, serta menyukai kegiatan mencoba-coba.

Subjek penelitian ini adalah semua siswa kelas X SMAK St. Petrus Ende tahun ajaran 2019/2020, yang berjumlah 189 orang. Sugiyono (2014) menyarankan untuk mengurangi kesalahan generalisasi hasil penelitian sebaiknya jumlah sampel yang diambil makin besar dan bahkan sama dengan jumlah populasi itu sendiri. Dalam penelitian ini, jumlah sampel yang diambil sama dengan jumlah populasi.

Dalam penelitian ini, peneliti menggunakan angket atau kuesioner sebagai instrumen penelitian. Angket berisikan sejumlah pertanyaan tertulis yang digunakan untuk memperoleh informasi dari subjek penelitian (Supraktiknya, 2015) dalam hubungan dengan karakteristik gaya belajarnya. Instrumen angket tidak diuji coba tetapi hanya divalidasi oleh ahli bahasa untuk menghindari adanya pemaknaan ganda atau ambigu terhadap pertanyaan di dalamnya. Ditinjau dari cara menjawab, angket yang digunakan merupakan angket tertutup, di mana telah disediakan tiga alternatif jawaban. Responden diminta untuk memilih jawaban 
yang paling sesuai dengan dirinya (Supraktiknya, 2015). Ditinjau dari jawabannya, angket yang digunakan dalam penelitian ini adalah angket langsung sebab subjek penelitian langsung menjawab pertanyaan tentang dirinya.

Instrumen angket digunakan dalam penelitian ini untuk memperoleh data tentang karakteristik gaya belajar siswa kelas X SMAK St. Petrus Ende tahun ajaran 2019/2020. Sedangkan untuk mendapatkan data dan penjelasan tentang karakteristik gaya belajar VAK dan strategi pembelajaran, peneliti melakukan studi kepustakaan (library research). Sumber pustaka untuk mendeskripsikan strategi pembelajaran dalam penelitian ini berupa jurnal penelitian, laporan penelitian, buku teks, dan terbitan resmi pemerintah atau lembaga-lembaga lain yang relevan. Dari sumber yang diteliti peneliti berusaha untuk menemukan ide baru dan menyajikannya secara baru.

Analisis data dilakukan dengan cara merekapitulasi data angket yang diperoleh dari setiap responden berdasarkan masing-masing gaya belajar (Sari, 2014). Sedangkan langkah-langkah analisis data dalam penelitian ini adalah:

1. Subjek penelitian menjawab dua puluh (20) pertanyaan angket. Setiap pertanyaan memiliki 3 alternatif jawaban. Setiap jawaban mencerminkan gaya belajar tertentu yang kemudian akan dikelompokkan dalam kelompok $A$ untuk gaya belajar visual, kelompok B untuk gaya belajar auditorial, dan kelompok C untuk gaya belajar kinestetik.

2. Setiap jawaban atas pertanyaan tentang gaya belajar diberikan skor atau nilai 1.

3. Penarikan kesimpulan kecenderungan gaya belajar dilakukan dengan cara membandingkan jumlah nilai yang didapat oleh subjek penelitian. Penarikan kesimpulan didasarkan pada:

a. Jika terdapat nilai tertinggi pada suatu kelompok gaya belajar, maka disimpulkan subjek tersebut cenderung dominan pada gaya belajar tersebut;

b. Jika terdapat dua nilai tertinggi yang sama dari dua kelompok gaya belajar, maka subjek tersebut digolongkan pada "gabungan kedua gaya belajar" tersebut;

c. Jika terdapat dua nilai tertinggi dari dua kelompok gaya belajar yang berselisih satu (1) poin, maka subjek tersebut digolongkan pada "gabungan kedua gaya belajar" tersebut. 
4. Sesudah itu, akan dibuat rekapitulasi persentase kecenderungan gaya belajar secara keseluruhan dari siswa kelas X SMAK St. Petrus Ende tahun ajaran 2019/2020.

\section{HASIL PENELITIAN}

Setelah angket gaya belajar diisi oleh 189 subjek penelitian, peneliti melakukan penghitungan dan menganalisis skor setiap subjek penelitian. Dari analisis skor tersebut, peneliti menarik kesimpulan kecenderungan gaya belajar dari setiap subjek lalu mengelompokkannya. Dalam penelitian ini secara keseluruhan ditemukan 6 kelompok kecenderungan gaya belajar, yaitu:

1. Visual (disimbolkan "V")

2. Auditorial (disimbolkan "A")

3. Kinestetik (disimbolkan "K")

4. Gabungan Visual dan Auditorial (disimbolkan "VA")

5. Gabungan Visual dan Kinestetik (disimbolkan "VK")

6. Gabungan Auditorial dan Kinestetik (disimbolkan "AK")

Hasil penelitian ini sejalan dengan hasil penelitian yang dilakukan oleh Sari (2014). Namun bila ditelusuri tiap kelas paralel, pada kelas Xd ditemukan 5 kelompok gaya belajar, yakni visual, auditorial, kinestetik, gabungan visual auditorial, dan gabungan auditorial kinestetik. Hasil penelitian ini diuraikan dalam dua poin berikut ini.

A. Kecenderungan Gaya Belajar Tiap Kelas Paralel Pada Siswa Kelas X SMAK St. Petrus Ende Tahun Ajaran 2019/2020

Siswa kelas X SMAK St. Petrus Ende tahun ajaran 2019/2020 terdiri atas lima (5) kelas paralel, yaitu kelas $\mathrm{Xa}, \mathrm{Xb}, \mathrm{Xc}, \mathrm{Xd}$ dan $\mathrm{Xe}$. Hasil analisis kecenderungan gaya belajar siswa kelas Xa SMAK St. Petrus Ende tahun ajaran $2019 / 2020$ adalah visual $15,80 \%$, auditorial $50,00 \%$, kinestetik $2,63 \%$, gabungan visual dan auditorial 18,42\%, gabungan visual dan kinestetik 2,63\%, dan gabungan auditoral dan kinestetik 7,89\%. Siswa yang mengisi angket namun tidak lengkap sebanyak 2,63\%. Dengan demikian, kecenderungan gaya belajar siswa kelas Xa adalah gaya belajar auditorial. Data lengkap kecenderungan gaya belajar siswa kelas Xa dapat dilihat dalam Tabel 1. 
Tabel 1. Kecenderungan Gaya Belajar Siswa Kelas Xa SMAK St. Petrus Tahun Ajaran 2019/2020

\begin{tabular}{llll}
\hline No & Gaya Belajar & Frekuensi & Persentase \\
\hline $\mathbf{1}$ & V & 6 & $15,80 \%$ \\
$\mathbf{2}$ & $\mathrm{A}$ & 19 & $50,00 \%$ \\
$\mathbf{3}$ & K & 1 & $2,63 \%$ \\
$\mathbf{4}$ & VA & 7 & $18,42 \%$ \\
$\mathbf{5}$ & VK & 1 & $2,63 \%$ \\
$\mathbf{6}$ & AK & 3 & $7,89 \%$ \\
$\mathbf{7}$ & Angket yang diisi tidak lengkap & 1 & $2,63 \%$ \\
\cline { 2 - 3 } & Total & 38 & $100 \%$ \\
\cline { 2 - 3 } & & &
\end{tabular}

Hasil analisis kecenderungan gaya belajar siswa kelas Xb SMAK St. Petrus Ende tahun ajaran $2019 / 2020$ adalah visual $15,80 \%$, auditorial $60,53 \%$, kinestetik $5,26 \%$, gabungan visual dan auditorial 7,89\%, gabungan visual dan kinestetik $7,89 \%$, dan gabungan auditorial dan kinestetik 2,63\%. Dengan demikian, kecenderungan gaya belajar siswa kelas $\mathrm{Xb}$ adalah gaya belajar auditorial. Data lengkap kecenderungan gaya belajar siswa kelas Xb dapat dilihat dalam Tabel 2.

Tabel 2. Kecenderungan Gaya Belajar Siswa Kelas Xb SMAK St. Petrus Tahun Ajaran 2019/2020

\begin{tabular}{llll}
\hline No & Gaya Belajar & Frekuensi & Persentase \\
\hline $\mathbf{1}$ & V & 6 & $15,80 \%$ \\
$\mathbf{2}$ & A & 23 & $60,53 \%$ \\
$\mathbf{3}$ & K & 2 & $5,26 \%$ \\
$\mathbf{4}$ & VA & 3 & $7,89 \%$ \\
$\mathbf{5}$ & VK & 3 & $7,89 \%$ \\
$\mathbf{6}$ & AK & 1 & $2,63 \%$ \\
$\mathbf{7}$ & Angket yang diisi tidak lengkap & - & - \\
\cline { 2 - 4 } & Total & 38 & $100 \%$ \\
\cline { 2 - 4 } & & &
\end{tabular}

Hasil analisis kecenderungan gaya belajar siswa kelas Xc SMAK St. Petrus Ende tahun ajaran 2019/2020 adalah visual 5,26\%, auditorial 68,42\%, kinestetik $2,63 \%$, gabungan visual dan auditorial $15,80 \%$, dan gabungan auditorial dan kinestetik $7,89 \%$. Ada pun gaya belajar gabungan visual dan kinestetik tidak ditemukan pada siswa kelas Xc. Dengan demikian, kecenderungan gaya belajar siswa kelas Xc adalah gaya belajar auditorial. Data lengkap kecenderungan gaya belajar siswa kelas Xc dapat dilihat dalam Tabel 3. 
Tabel 3. Kecenderungan Gaya Belajar Siswa Kelas Xc SMAK St. Petrus Tahun Ajaran $2019 / 2020$

\begin{tabular}{llll}
\hline No & Gaya Belajar & Frekuensi & Persentase \\
\hline $\mathbf{1}$ & V & 2 & $5,26 \%$ \\
$\mathbf{2}$ & A & 26 & $68,42 \%$ \\
$\mathbf{3}$ & K & 1 & $2,63 \%$ \\
$\mathbf{4}$ & VA & 6 & $15,80 \%$ \\
$\mathbf{5}$ & VK & - & - \\
$\mathbf{6}$ & AK & 3 & $7,89 \%$ \\
$\mathbf{7}$ & Angket yang diisi tidak lengkap & - & - \\
\cline { 2 - 4 } & Total & 38 & $100 \%$ \\
\cline { 2 - 4 } & & &
\end{tabular}

Hasil analisis kecenderungan gaya belajar siswa kelas Xd SMAK St. Petrus Ende tahun ajaran $2019 / 2020$ adalah visual 2,70\%, auditorial $29,73 \%$, kinestetik $10,81 \%$, gabungan visual dan auditorial $37,84 \%$, dan gabungan auditorial dan kinestetik 13,51\%. Sedangkan gaya belajar gabungan visual dan kinestetik tidak ditemukan pada siswa kelas $\mathrm{Xd}$. Siswa yang mengisi angket namun tidak lengkap sebanyak 5,41\%. Dengan demikian, kecenderungan gaya belajar siswa kelas Xd adalah gaya belajar gabungan visual dan auditorial. Data lengkap kecenderungan gaya belajar siswa kelas Xd dapat dilihat dalam Tabel 4.

Tabel 4. Kecenderungan Gaya Belajar Siswa kelas Xd SMAK St. Petrus Tahun Ajaran 2019/2020

\begin{tabular}{llll}
\hline No & Gaya Belajar & Frekuensi & Persentase \\
\hline $\mathbf{1}$ & V & 1 & $2,70 \%$ \\
$\mathbf{2}$ & A & 11 & $29,73 \%$ \\
$\mathbf{3}$ & K & 4 & $10,81 \%$ \\
$\mathbf{4}$ & VA & 14 & $37,84 \%$ \\
$\mathbf{5}$ & VK & - & - \\
$\mathbf{6}$ & AK & 5 & $13,51 \%$ \\
$\mathbf{7}$ & Angket yang diisi tidak lengkap & 2 & $5,41 \%$ \\
\cline { 2 - 4 } & Total & 37 & $100 \%$ \\
\cline { 2 - 4 } & & &
\end{tabular}

Hasil analisis kecenderungan gaya belajar siswa kelas Xe SMAK St. Petrus Ende tahun ajaran $2019 / 2020$ adalah visual $7,89 \%$, auditorial $55,27 \%$, kinestetik $7,89 \%$, gabungan visual dan auditorial $21,06 \%$, gabungan visual dan kinestetik 2,63\%, dan gabungan auditorial dan kinestetik 5,26\%. Dengan demikian, kecenderungan gaya belajar siswa kelas Xe adalah gaya belajar auditorial. Data lengkap kecenderungan gaya belajar siswa kelas Xe dapat dilihat dalam Tabel 5. 
Tabel 5. Kecenderungan Gaya Belajar Siswa Kelas Xe SMAK St. Petrus Tahun Ajaran 2019/2020

\begin{tabular}{cccc}
\hline No & Gaya Belajar & Frekuensi & Persentase \\
\hline $\mathbf{1}$ & $\mathrm{V}$ & 3 & $7,89 \%$ \\
$\mathbf{2}$ & $\mathrm{A}$ & 21 & $55,27 \%$ \\
$\mathbf{3}$ & $\mathrm{K}$ & 3 & $7,89 \%$ \\
$\mathbf{4}$ & $\mathrm{VA}$ & 8 & $21,06 \%$ \\
$\mathbf{5}$ & VK & 1 & $2,63 \%$ \\
$\mathbf{6}$ & AK & 2 & $5,26 \%$ \\
$\mathbf{7}$ & Angket yang diisi tidak lengkap & - & - \\
\cline { 2 - 4 } & Total & 38 & $100 \%$ \\
\cline { 2 - 4 } & & &
\end{tabular}

B. Kecenderungan Gaya Belajar Secara Umum Pada Siswa Kelas X SMAK St. Petrus Tahun Ajaran 2019/2020

Analisis kecenderungan gaya belajar keseluruhan siswa kelas X SMAK St. Petrus tahun ajaran 2019/2020 dilakukan dengan cara menjumlahkan seluruh frekuensi siswa dari tiap kelas dengan kecenderungan gaya belajar yang sama. Hasil penjumlahannya adalah visual 9,52\%, auditorial 52,91\%, kinestetik 5,82\%, gabungan visual dan auditorial $20,11 \%$, gabungan visual dan kinestetik $2,65 \%$, dan gabungan auditorial dan kinestetik $7,41 \%$. Siswa yang mengisi angket namun tidak lengkap sebanyak $1,58 \%$. Rincian analisis data kecenderungan gaya belajar siswa kelas X SMAK St. Petrus tahun ajaran 2019/2020 dapat dilihat dalam Tabel 6.

Tabel 6. Kecenderungan Gaya Belajar Siswa Kelas X SMAK St. Petrus Ende Tahun Ajaran 2019/2020

\begin{tabular}{ccccccccc}
\hline \multirow{2}{*}{ No } & \multirow{2}{*}{ Gaya Belajar } & \multicolumn{7}{c}{ Frekuensi } \\
\cline { 3 - 8 } & & $\mathrm{Xa}$ & $\mathrm{Xb}$ & $\mathrm{Xc}$ & $\mathrm{Xd}$ & $\mathrm{Xe}$ & $\mathrm{T}$ & \multirow{2}{*}{ Persentase } \\
\hline $\mathbf{1}$ & $\mathrm{V}$ & 6 & 6 & 2 & 1 & 3 & 18 & $9,52 \%$ \\
$\mathbf{2}$ & $\mathrm{A}$ & 19 & 23 & 26 & 11 & 21 & 100 & $52,91 \%$ \\
$\mathbf{3}$ & $\mathrm{K}$ & 1 & 2 & 1 & 4 & 3 & 11 & $5,82 \%$ \\
$\mathbf{4}$ & VA & 7 & 3 & 6 & 14 & 8 & 38 & $20,11 \%$ \\
$\mathbf{5}$ & VK & 1 & 3 & - & - & 1 & 5 & $2,65 \%$ \\
$\mathbf{6}$ & AK & 3 & 1 & 3 & 5 & 2 & 14 & $7,41 \%$ \\
$\mathbf{7}$ & Angket yang diisi & 1 & & & 2 & & 3 & $1,58 \%$ \\
& tidak lengkap & & & & & & & \\
\cline { 2 - 7 } & Total & 38 & 38 & 38 & 37 & 38 & 189 & $100 \%$ \\
\hline
\end{tabular}

Keterangan Tabel 6:

$\mathrm{Xa}$ : frekuensi masing-masing tipe gaya belajar kelas $\mathrm{Xa}$

$\mathrm{Xb}$ : frekuensi masing-masing tipe gaya belajar kelas $\mathrm{Xb}$

$X_{c}$ : frekuensi masing-masing tipe gaya belajar kelas $X_{c}$

$\mathrm{Xd}$ : frekuensi masing-masing tipe gaya belajar kelas $\mathrm{Xd}$

$\mathrm{Xe}$ : frekuensi masing-masing tipe gaya belajar kelas $\mathrm{Xe}$

$\mathrm{T}$ : total frekuensi masing-masing gaya belajar 


\section{DISKUSI}

\section{A. Karakteristik Gaya Belajar VAK dan Strategi Pembelajaran VAK}

Data penelitian di atas menunjukkan bahwa gaya belajar yang terdapat pada siswa kelas X SMAK St. Petrus Ende tahun ajaran 2019/2020 adalah gaya belajar auditorial 52,91\%, gaya belajar gabungan visual auditorial $20,11 \%$, gaya belajar visual $9,52 \%$, gaya belajar gabungan auditorial kinestetik $7,41 \%$, gaya belajar kinestetik 5,82\% dan gaya belajar gabungan visual kinestetik 2,66\%. Guru yang menginginkan agar proses pembelajaran pada mata pelajaran yang diampunya dapat diserap dengan baik oleh siswa, tentu membutuhkan pilihan strategi pembelajaran yang sesuai dengan gaya belajar siswa. Di bawah ini hanya akan dijelaskan karakteristik gaya belajar visual, auditorial, kinestetik dan strategi pembelajaran yang cocok untuk masing-masing gaya belajar. Karakteristik gaya belajar gabungan merupakan paduan dari kedua gaya belajar tersebut dan strategi pembelajarannya juga merupakan gabungan dari keduanya.

\section{Karakteristik Gaya Belajar Auditorial dan Strategi Pembelajaran yang Cocok}

Uno (2016) menjelaskan bahwa gaya belajar auditorial adalah gaya belajar yang menempatkan pendengaran sebagai alat utama dalam menyerap informasi dan pengetahuan. Dalam kehidupan sehari-hari siswa yang memiliki gaya belajar ini sangat baik dalam hal aktivitas lisan. Itu berarti $52,91 \%$ siswa kelas X SMAK St. Petrus Ende tahun ajaran 2019/2020 yang memiliki gaya belajar auditorial belajar dengan cara mendengarkan dan dapat berbicara dengan baik, dapat bercerita dengan baik namun memiliki kesulitan dalam menulis. Mereka biasanya belajar dengan cara membaca keras, sehingga dapat mengakibatkan kelas menjadi rebut.

Rincian karakteristik siswa dengan gaya belajar auditorial dijelaskan oleh Gantasala dan Gantasal (2009), Hasrul (2009), De Porter dan Hernacki (2000), Wiyani (2013), dan Uno (2016) sebagai berikut: a) semua informasi hanya bisa diserap melalui pendengaran; b) kesulitan menyerap informasi dalam bentuk tulisan secara langsung; c) memiliki kesulitan untuk menulis atau membaca; d) berbicara dengan tempo yang teratur atau ritmis, dengan nada yang sedang, serta berbicara kepada diri sendiri saat kerja; e) mudah terganggu oleh keributan; f) membaca dengan menggerakkan bibir, bahkan membaca dengan keras dan mendengarkan; g) seorang pendengar yang baik; h) dapat mengulangi kembali 
dan menirukan nada, birama, dan warna suara; i) merasa kesulitan untuk menulis tetapi hebat dalam bercerita; j) biasanya menyukai musik; k) belajar dengan mendengarkan dan mengingat apa yang didiskusikan daripada apa yang dilihat, atau lebih mudah mengingat apa yang didengarnya; I) suka berbicara, suka berdiskusi dan menjelaskan sesuatu secara panjang lebar; m) mempunyai masalah dengan pekerjaan-pekerjaan yang melibatkan visualisasi, seperti memotong bagian-bagian hingga sesuai satu sama lain; $n$ ) lebih pandai mengeja dengan keras daripada menuliskannya; o) lebih suka gurauan lisan daripada membaca komik; p) berdialog secara internal dan eksternal serta mereka adalah pembicara yang baik.

Strategi pembelajaran dan metode komunikasi efektif yang dapat dilakukan oleh guru bagi siswa yang memiliki gaya belajar auditorial adalah dengan menggunakan teknik pengulangan. Hasrul (2009), Rahmawati (Chania, Haviz, \& Sasmita, 2016), dan Sari (2014) menawarkan beberapa strategi pembelajaran yang cocok bagi siswa yang bergaya auditorial yang dapat dilakukan guru dan siswa.

Guru dianjurkan untuk melakukan hal-hal berikut dalam proses pembelajaran: a) guru memberikan informasi secara berulang-ulang; b) guru meminta siswa untuk menyebutkan kembali konsep dan petunjuk; c) guru menggunakan variasi vokal (perubahan nada, kecepatan dan volume) dalam presentasi; d) guru menyanyikan konsep kunci atau meminta siswa untuk menciptakan lagu terkait konsep tersebut atau mengulangi nyanyian yang diajarkan guru; e) guru memberi dorongan kepada siswa untuk membuat atau memikirkan "jembatan keledai" agar mempermudahnya dalam menghafalkan atau mengingat konsep-konsep kunci; f) guru menggunakan metode tanya jawab, bermain peran, kerja kelompok; g) guru dapat menggunakan musik dalam proses pembelajaran.

Siswa auditorial dapat melakukan hal-hal berikut: a) menggunakan voice recorder atau perekam suara saat mendengarkan pelajaran dan mendengarkan kembali pelajaran melalui rekaman tersebut. Bila tidak merekam, siswa dapat meminta penjelasan dari teman atau orang lain tentang pelajaran tersebut; b) menggunakan pengulangan dan menyebutkan kembali konsep-konsep kunci yang telah didengar; c) membuat suatu konsep kunci menjadi nyanyian yang mudah diingat dan dipahami serta dihafalkan, dan melagukan apa yang dingat dengan irama yang disukai serta menghindari "polusi suara" atau kebisingan; d) berpikir 
dan mengingat sambil mengucapkannya kembali; e) menggunakan musik sebagai bagian dari kegiatan belajar.

\section{Karakteristik Gaya Belajar Visual dan Strategi Pembelajaran yang Cocok}

Siswa kelas X SMAK St. Petrus Ende tahun ajaran 2019/2020 yang memiliki gaya belajar visual sebanyak 18 orang atau $9,52 \%$. Itu berarti kedelapan belas siswa ini belajar dengan cara melihat, mengamati, memandang dan sejenisnya. Indra yang mereka andalkan dalam belajar adalah indra penglihatan.

Menurut De Porter dan Hernacki (2000), Gantasala dan Gantasal (2009), Wiyani (2013), Hasrul (2009) dan Uno (2016) siswa dengan gaya belajar visual memiliki ciri-ciri berikut: a) kebutuhan melihat sesuatu (informasi atau penjelasan) secara visual untuk mengetahuinya atau memahaminya; b) memiliki kepekaan yang kuat terhadap warna; c) memiliki pemahaman yang cukup terhadap masalah artistik; d) memiliki kesulitan dalam berdialog secara langsung; e) terlalu reaktif terhadap suara; f) sulit mengikuti anjuran secara lisan; g) sering salah menginterpretasikan kata atau ucapan; h) rapi dan teratur, memperhatikan segala sesuatu, menjaga penampilan; i) berbicara dengan cepat dan dengan nada yang tinggi; j) berjalan dengan cepat, seolah terburu-buru; k) menjawab pertanyaan dengan jawaban yang singkat; I) mayoritas tipe visual suka membaca, namun buku bacaan yang banyak memiliki gambar ilustrasi dan warna yang menarik lebih mudah dipahami daripada buku bacaan yang penuh dengan teks; $\mathrm{m}$ ) mengingat apa yang dilihat daripada apa yang didengar; n) lebih suka membaca daripada dibacakan, pembaca cepat, teliti dan tekun; o) sering mengetahui apa yang harus dikatakan tetapi tidak pandai memilih kata-kata; p) mengingat asosiasi visual; dan r) perencana yang baik.

Strategi pembelajaran dan metode komunikasi yang efektif yang dapat dilakukan oleh para guru yang mengajar siswa kelas X SMAK St. Petrus Ende bagi siswa yang memiliki gaya belajar visual adalah dengan menggunakan alat bantu visual dan menjelaskan secara visual. Harsul (2009); Rahmawati (Chania, Haviz, \& Sasmita, 2016) dan Sari (2014) menawarkan beberapa strategi pembelajaran yang cocok bagi siswa yang bergaya visual yang dapat dilakukan oleh guru dan siswa.

Guru dianjurkan untuk melakukan hal-hal berikut dalam proses pembelajaran: a) berdiri tenang saat menyajikan segmen informasi dan bergerak secara perlahan di antara segmen tersebut; b) memberikan dorongan kepada siswa untuk menggambarkan informasi dengan membuat diagram, simbol atau 
gambar berwarna dalam catatan siswa visual; c) mengajak siswa untuk coba mengilustrasikan ide-idenya ke dalam gambar; d) memberi penjelasan dengan menggunakan tabel dan grafik akan memperdalam pemahaman siswa visual terutama pelajaran matematika, teknik, atau ilmu pengetahuan alam (IPA); e) membuat peta pikiran atau peta konsep yang akan sangat membantu siswa visual dalam menggambarkan keseluruhan suatu konsep; f) menggunakan materi visual dalam presentasi atau penjelasan yang mewakili konsep kunci, seperti gambar, diagram atau peta; g) membiasakan siswa untuk mencatat kembali informasi atau materi dengan menggunakan aneka warna atau gambar yang menarik; h) memperhatikan penerangan atau pencahayaan ruangan saat belajar atau pembelajaran berlangsung; i) menggunakan media pembelajaran berupa buku, majalah, poster, komputer atau LCD, kata kunci yang dipajang di sekeliling kelas, ditulis dengan tulisan berwarna yang menarik.

Siswa visual dapat melakukan hal-hal berikut: a) menggunakan variasi warna dalam melakukan pencatatan, seperti memberi garis bawah atau membuat grafik; b) memerhatikan penerangan saat belajar dan menghindari "polusi visual"; c) saat mengingat sesuatu, membayangkan dan membuat tulisan yang memudahkan; d) mencatat kembali pelajaran dengan warna dan gambar menarik; e) menggunakan simbol-simbol untuk mewakili konsep, f) menggunakan warna untuk meng-high-light hal-hal penting, g) menggunakan kertas tulis dengan tulisan berwarna; h) membuat diagram, peta dan mewarnainya untuk menggambarkan informasi yang ada; i) memahami konsep secara keseluruhan sebelum terjun ke bagian detailnya; j) memberikan kode warna untuk bahan pelajaran; dan k) menggunakan simbol-simbol untuk mewakili konsep.

\section{Karakteristik Gaya Belajar Kinestetik dan Strategi Pembelajaran yang Cocok}

Hasil penelitian menunjukkan bahwa terdapat 11 siswa kelas X SMAK St. Petrus Ende atau 5,82\% yang memiliki gaya belajar kinestetik. Siswa yang memiliki gaya belajar ini belajar dengan mengutamakan indra perasa dan gerakangerakan fisik. Mereka belajar dengan cara bergerak, bekerja dan menyentuh atau belajar dengan cara terlibat langsung.

Gantasala dan Gantasal (2009), Hasrul (2009), De Porter dan Hernacki (2000), Wiyani (2013) dan Uno (2016) merincikan karakteristik gaya belajar kinestetik sebagai berikut: a) menempatkan tangan sebagai alat penerima informasi utama agar bisa terus mengingatnya; b) hanya dengan memegang, 
orang yang memiliki gaya belajar kinestetik dapat menyerap informasinya tanpa harus membaca penjelasannya; c) tidak sanggup duduk terlalu lama untuk mendengarkan pelajaran; d) merasa dapat belajar dengan lebih baik apabila disertai dengan kegiatan fisik; e) memiliki kemampuan untuk mengkoordinasikan sebuah tim dan kemampuan mengendalikan gerak tubuh (atheletic ability); f) berbicara dengan perlahan, dalam tempo yang lambat, banyak jeda dan nada yang dalam; g) menanggapi perhatian fisik, berjalan dengan cukup lambat, seolah terlihat malas atau tidak bergairah; h) menyentuh orang untuk mendapatkan perhatian mereka, terutama pada saat berbicara; i) berdiri dekat dengan lawan bicara ketika berbicara; j) selalu berorientasi pada fisik dan banyak bergerak, lebih suka menyentuh, merasakan dan memegang sesuatu; k) mempunyai perkembangan awal otot-otot yang besar; I) belajar melalui memanipulasi dan praktik, mencoba secara langsung, dipraktikkan untuk mengetahui kesalahannya agar dapat diperbaiki lagi, serta sangat mudah menguasai sesuatu hal dengan cara otodidak; m) konsentrasi mudah terganggu oleh suatu keributan, n) menghafal atau mengingat dengan cara berjalan dan melihat, menggunakan jari sebagai penunjuk ketika membaca; o) banyak menggunakan isyarat tubuh; $p$ ) tidak dapat duduk diam untuk waktu yang lama, selalu ada anggota tubuhnya yang digerakkan secara kontinu, misalnya kaki; q) tidak dapat mengingat geografi, kecuali jika mereka memang pernah berada di tempat tersebut; r) menggunakan kata-kata yang mengandung aksi; s) menyukai buku-buku yang berorientasi pada plot - mereka akan menunjukkan aksi dengan gerakan tubuh pada saat membaca; t) pada umumnya tulisan tangan mereka jelek; $u$ ) ingin melakukan segala sesuatu dan menyukai permainan yang menyibukkan.

Guru dapat menggunakan alat peraga atau alat bantu atau suatu subjek, untuk menimbulkan rasa ingin tahu sebagai strategi pembelajaran dan metode komunikasi yang efektif bagi siswa yang memiliki gaya belajar kinestetik (Hasrul, 2009); Wulandari (Chania, Haviz, \& Sasmita, 2016), dan (Sari, 2014) menawarkan beberapa strategi pembelajaran yang cocok bagi siswa yang bergaya kinestetik, yang dapat dilakukan oleh guru dan siswa. Guru dianjurkan untuk melakukan halhal berikut dalam proses pembelajaran, yaitu a) menggunakan media pembelajaran atau alat bantu, atau alat peraga pada saat mengajar untuk menimbulkan rasa ingin tahu dan menekankan konsep kunci; b) memberikan tugas bagi siswa kinestetik berupa proyek terapan; c) mengizinkan siswa kinestetik berjalan-jalan di dalam kelas; d) memperagakan konsep sambil memberikan 
kesempatan kepada siswa untuk mempelajarinya langkah demi langkah; e) menciptakan simulasi konsep agar siswa mengahaminya; f) membuat peta pikiran dengan melibatkan aktivitas fisik, yang mana hal ini akan sangat bermanfaat bagi siswa kinestetik.

Siswa kinestetik dapat melakukan hal-hal berikut: a) menggunakan alat bantu dalam belajar untuk membangkitkan atau menimbulkan rasa ingin tahu dan untuk menekankan konsep-konsep kunci; b) menggunakan gerakan fisik dalam belajar, seperti uji coba secara langsung; c) melakukan simulasi konsep agar mudah dipahami; d) pada saat diberikan bimbingan oleh guru, siswa duduk di dekatnya atau di sebelahnya; e) memperagakan konsep untuk mempelajari langkah demi langkah, atau memperbanyak praktik yang berkaitan dengan pelajaran (praktik di dalam laboratorium) dan langsung bisa diaplikasikan; f) melakukan gerakan-gerakan fisik saat belajar untuk mempermudah proses mengingat; g) menghindari cara belajar yang terlalu monoton, seperti terlalu banyak duduk; h) saat mengingat sesuatu, perlu dilakukan hal yang diingat dengan aktivitas gerakan; i) menulis di udara atau menggunakan gerakan imajinatif.

\section{B. Kelebihan dan Kelemahan Pembelajaran dengan Menggunakan Gaya Belajar VAK}

Pembelajaran dengan menggunakan gaya belajar VAK memiliki beberapa kelebihan dan kelemahan (Janghyunita, 2012; Wahyuni \& Konadi, 2015). Kelebihan pembelajaran dengan menggunakan gaya belajar VAK adalah a) dengan mengkombinasikan ketiga gaya belajar (visual, auditorial dan kinestetik) membuat proses pembelajaran akan menjadi lebih efektif; b) potensi siswa yang telah dimilikinya secara pribadi dapat dikembangkan dengan lebih baik; c) suasana belajar menjadi lebih baik, menarik dan efektif; d) memberikan pengalaman langsung kepada siswa dengan melibatkan siswa melalui kegiatan fisik seperti demonstrasi, percobaan, observasi, dan diskusi aktif; e) mampu menjangkau gaya belajar setiap siswa, sehingga siswa yang memiliki kemampuan lebih baik tidak terhambat oleh siswa yang lemah dalam belajar. Kelemahan pembelajaran dengan menggunakan gaya belajar VAK adalah tidak banyak orang yang sanggup mengkombinasikan ketiga gaya belajar tersebut secara seimbang. Umumnya orang lebih cenderung menggunakan gaya belajar yang dominan dalam mempelajari sesuatu.

Berdasarkan tujuan penelitian dan hasil beserta pembahasan, maka dapat diperoleh beberapa kesimpulan berikut: 
1. Gaya belajar yang dominan pada siswa kelas Xa SMAK St. Petrus Ende tahun ajaran 2019/2020 adalah gaya belajar auditorial sebanyak $50,00 \%$ dari total siswa pada kelas tersebut.

2. Gaya belajar yang dominan pada siswa kelas Xb SMAK St. Petrus Ende tahun ajaran $2019 / 2020$ adalah gaya belajar auditorial $60,53 \%$ dari total siswa pada kelas tersebut.

3. Gaya belajar yang dominan pada siswa kelas Xc SMAK St. Petrus Ende tahun ajaran 2019/2020 adalah gaya belajar auditorial sebanyak $68,42 \%$ dari total siswa pada kelas tersebut.

4. Gaya belajar yang dominan pada siswa kelas Xd SMAK St. Petrus Ende tahun ajaran 2019/2020 adalah gaya belajar gabungan visual dan auditorial sebanyak $37,84 \%$ dari total siswa pada kelas tersebut.

5. Gaya belajar yang dominan pada siswa kelas Xe SMAK St. Petrus Ende tahun ajaran 2019/2020 adalah gaya belajar auditorial sebanyak $55,27 \%$ dari total siswa pada kelas tersebut.

6. Secara keseluruhan gaya belajar siswa kelas X SMAK St. Petrus Ende angkatan 2019/2020 didominasi oleh gaya belajar auditorial, yaitu sebesar $52,91 \%$.

Mencermati hasil penelitian yang telah diperoleh maka beberapa saran penelitian yang dapat diberikan adalah bagi para guru diharapkan dapat merancang atau mendesain strategi pembelajaran yang mampu melibatkan banyak gaya belajar siswa secara bersamaan sehingga dapat mencapai hasil belajar yang maksimal. Untuk siswa diharapkan setelah mengetahui kecenderungan gaya belajarnya, siswa mampu memanfaatkan gaya belajar tersebut dalam menyerap informasi dan dalam mempelajari ilmu pengetahuan sehingga meningkatkan pemahaman terhadap materi ajar. Sedangkan bagi peneliti selanjutnya, disarankan agar dapat mengembangkan penelitian ini, misalnya untuk meneliti hubungan gaya belajar siswa dengan hasil belajar siswa pada mata pelajaran Pendidikan Agama Katolik (PAK).

\section{DEKLARASI KEPENTINGAN}

Penelitian ini dilakukan demi perkembangan ilmu pengetahuan. Tidak ada konflik kepentingan maupun finansial dalam seluruh proses penelitian ini. 


\section{PENDANAAN}

Penelitian ini didanai oleh Yayasan Persekolah St. Petrus Ende. Yayasan ini membawahi STIPAR Ende dan SMAK St. Petrus Ende.

\section{PENUTUP}

Penelitian ini dapat berjalan dengan baik berkat bantuan Yayasan Persekolahan St. Petrus Ende, kepala sekolah, para guru dan tenaga kependidikan SMAK St. Petrus Ende serta para siswa kelas X SMAK St. Petrus Ende tahun ajaran 2019/2020. Karena itu, peneliti menyampaikan ucapan terima kasih berlimpah kepada semua pihak yang telah menolong peneliti selama proses penelitian ini.

\section{REFERENSI}

Awla, H.A. (2014). Learning Styles And Their Relation To Teaching Styles. International Journal of Language and Linguistics 2 (3), 241-245.

Bire, A.L. - Gerardus, U. - Bire, J. (2014). Pengaruh Gaya Belajar Visual, Auditorial dan Kinestetik Terhadap Prestasi Belajar Siswa. Jurnal Kependidikan 44 (2), 168-174.

Chania, Y. - Haviz, M. - Sasmita, D. (2016). Hubungan Gaya Belajar dengan Hasil Belajar Siswa pada Pembelajaran Biologi Kelas X SMAN 2 Sungai Tarab Kabupaten Tanah Datar. Journal of Sainstek 8 (1), 77- 84.

DePorter, D. \& M. Hernacki (2000). Quantum Learning: Membiasakan Belajar Nyaman dan Menyenangkan. Bandung: Kayfa.

Direktorat Tenaga Kependidikan (2008). Strategi Pembelajaran Dan Pemilihannya, Direktorat Jenderal Peningkatan Mutu Pendidik Dan Tenaga Kependidikan Departemen Pendidikan Nasional.

Gantasala, P.V. \& S.B. Gantasala (2009). Influence of Learning Styles. The International Journal of Learning 16 (9).

Ghufron, M.N. \& R. Risnawita (2013). Gaya Belajar Kajian Teoretik. Yogyakarta: Pustaka Pelajar.

Hasrul (2009). Pemahaman Tentang Gaya Belajar. Journal Medtek 1 (2).

Kurniawan, M.R. (2017). Analisis Karakter Media Pembelajaran Berdasarkan Gaya Belajar Peserta Didik. JInoP (Jurnal Inovasi Pembelajaran) 3 (1).

Papilaya, J.O. \& N. Huliselan (2016). Identifikasi Gaya Belajar Mahasiswa. Jurnal Psikologi Undip 15 (1), 56-63.

Reber, A.S. \& E.S. Reber (2016). Kamus Psikologi. Yogyakarta: Pustaka Pelajar. 
Rochintaniawati, D. - ulan, A.R. - Sriyati, S. (2009). Kebutuhan Guru Sekolah Dasar di Cimahi dan Kabupaten Bandung dalam Melangsungkan Pembelajaran IPA. Jurnal Penelitian 2 (10), 1-11.

Sari, A.K. (2014). Analisis Karakteristik Gaya Belajar VAK (Visual, Auditorial, Kinestetik) Mahasiswa Pendidikan Informatika Angkatan 2014. Jurnal IImiah Edutic 1 (1).

Sugiyono (2014). Metode Penelitian Kombinasi (Mixed Methods). Bandung: Alfabeta.

Sugiyono (2015). Metode Penelitian Kuantitatif, Kualitatif dan $R \& D$. Bandung: Alfabeta.

Sunhaji (2014). Konsep Manajemen Kelas dan Implikasinya dalam Pembelajaran. Jurnal Kependidikan 2 (2).

Supraktiknya, A. (2015). Metodologi Penelitian Kuantitatif dan Kualitatif dalam Psikologi. Yogyakarta: Universitas Sanata Dharma.

Talibo, I. (2013). Tipe-Tipe Belajar dalam Proses Pembelajaran. Jurnal IImiah Iqra $7(2)$.

Uno, H.B. (2016). Orientasi Baru dalam Psikologi Pembelajaran. Jakarta: Bumi Aksara.

Wahyuni, \& W. Konadi (2015). Upaya Meningkatkan Hasil Belajar Siswa dengan Menggunakan Model Pembelajaran VAK (Visual, Auditori, Kinestetik) pada Mata Pelajaran Ekonomi dengan Materi Pasar di Kelas VIII3 di SMPN Jangka. Jurnal Sains Ekonomi dan Edukasi 3 (1).

Wahyuni, Y. (2017). Identifikasi Gaya Belajar (Visual, Auditorial, Kinestetik) Mahasiswa Pendidikan Matematika Universitas Bung Hatta, JPPM 10 (2).

Wiyani, N.A. (2013). Manajemen Kelas. Teori dan Aplikasi Untuk Menciptakan Kelas Yang Kondusif. Yogyakarta: Ar-Ruzz Media. 